\title{
A pandémia hatása a személyes kapcsolathálózati struktúrára
}

\author{
Otthoni munkavégzés: \\ védelem a vírustól vagy társas izoláltság?
}

\author{
Dávid Beáta ${ }^{1,2 *}$, Herke Boglárka ${ }^{2,5}$, Huszti Éva ${ }^{3}$, Tóth Gergely ${ }^{2,4}$, \\ Túry-Angyal Emese ${ }^{2,5}$, Albert Fruzsina ${ }^{1,2}$ \\ ${ }^{1}$ Semmelweis Egyetem Mentálhigiéné Intézet, Budapest, Magyarország \\ ${ }^{2}$ Társadalomtudományi Kutatóközpont, MTA Kiváló Kutatóhely, ELKH, Budapest, Magyarország \\ ${ }^{3}$ Debreceni Egyetem Bölcsészettudományi Kar Politikatudományi és Szociológiai Intézet, Debrecen, Magyarország \\ ${ }^{4}$ Károli Gáspár Református Egyetem, Budapest, Magyarország \\ ${ }^{5}$ Szociológia és Kommunikációtudomány Doktori Iskola, Budapesti Corvinus Egyetem, Budapest, Magyarország
}

Beérkezett: 2021. augusztus 5.; Elfogadva: 2021. szeptember 1.

\begin{abstract}
Összefoglalás
Jelen írásban a biztonság három dimenziójának (egészség, munka, emberi kapcsolatok) összefüggésében a home office pozitív és negatív jellemzőit vizsgáljuk meg a pandémiás időszakban. Tanulmányunk egy 2020 májusában, reprezentatív mintán lekérdezett felmérés adataira épül, mely a vírushelyzetre vonatkozó kérdéseket és egy kapcsolati naplót tartalmazott. Az eredmények alapján a home office-ban dolgozók kevésbé voltak kitéve a fertőzésveszélynek: kevesebb időt töltöttek saját otthonukon kívül és tömegközlekedést is kevésbé használtak. Másrészt az otthonról dolgozók átlagosan kevesebb emberrel is találkoztak személyesen. A találkozásokban mutatkozó különbséget ugyanakkor kifejezetten a munkatársi kapcsolatok magyarázzák, míg a családi és baráti kapcsolataik megvédték az otthonról dolgozókat a társas izoláció veszélyétól.
\end{abstract}

Kulcsszavak: home office, társas kapcsolatok, COVID-19, kapcsolati napló, társas izoláció

\section{Effect of Covid-19 on personal network structures}

Home office: virus protection or social isolation?

Beata David ${ }^{1,2}$, Boglárka Herke ${ }^{2,5}$, Éva Huszti ${ }^{3}$, Gergely Tóth ${ }^{2,4}$, Emese Túry-Angyal2, ${ }^{2,5}$ Fruzsina Albert ${ }^{1,2}$

${ }^{1}$ Institute of Mental Health, Semmelweis University, Budapest, Hungary

${ }^{2}$ Centre for Social Sciences, HAS Centre of Excellence, Eötvös Loránd Research Network, Institute of Sociology, Budapest, Hungary

${ }^{3}$ University of Debrecen, Institute of Political Science and Sociology, Debrecen, Hungary

${ }^{4}$ Károli Gáspár University of the Reformed Church in Hungary, Budapest, Hungary

${ }^{5}$ Doctoral School of Sociology and Communication Science, Corvinus University of Budapest, Budapest, Hungary

\section{Summary}

The emergence of the Covid-19 virus in spring 2020 has significantly transformed the daily lives of the population. One of the major changes affecting the world of work is that many people have been able to work remotely from home. In this paper, we focus on the home office phenomenon with regard to the three dimensions of security (health, work and human relations) and examine its positive and negative impacts in the context of human relations during the pandemic. It is assumed that home office is more secure against the virus, as those working from home 
may choose not to leave their homes at all and thus protect themselves from the virus by being physically isolated. On the other hand, it is also assumed that home office workers encounter fewer people than non-home office workers and are therefore more vulnerable to social isolation.

In our study, we compare the characteristics of these two groups using descriptive statistics based on data from a national representative sample of 1,001 people contacted by telephone in May 2020. The survey included questions on the pandemic situation on the one hand, and a so-called contact diary on the other hand, in which respondents were asked to name all persons (and their characteristics) with whom they had spoken on that day beyond saying hello. First, the results show that home office workers were indeed less exposed to the risk of infection, as they spent significantly less time away from home, used public transport less, and none of them were abroad. Second, our data also show that there is a significant difference in the number of face-to-face encounters between home and non-home workers. Home office workers met on average two people face-to-face on the day of the survey, while non-home office workers met on average five people. While no significant difference was found in the number of relatives - whether or not they lived under the same roof as the respondent - between home office workers and those who went to work, the number of encounters with non-relatives was significantly higher among non-home office workers. The difference was mainly due to workplace contacts. This suggests that those working from home were protected from the risk of social isolation by their emotionally and physically close relationships. These results further support the finding that, in a crisis situation, the security provided by family ties is particularly valued and strong bonds are essential for the individual.

Keywords: home office, social network, COVID-19, contact diary, social isolation

\section{Bevezetés}

A 2020 tavaszán megjelenő COVID-19 vírus jelentősen átformálta a lakosság mindennapjait. Több szempontból, gyakran egymással ellentétes hatást kifejtve került fókuszba a biztonság, és annak különböző társadalmi dimenziói (Dávid et al. 2016). A fizikai egészségi állapot védelme érdekében, a munka és a személyes emberi kapcsolatok (akár rokoni, baráti vagy éppen munkahelyi kontaktok), és az ehhez kapcsolódó lelki egészség nyújtotta biztonság egyik pillanatról a másikra megrendült. A karantén alatt a munkavállalók világa jelentôsen megváltozott, mivel sokan távmunkában, otthonról is végezhették munkájukat. A KSH Munkaerö-felmérése szerint 2020 márciusában közel 8 százalékra, majd áprilisábanmájusában 17 százalékra nőtt a rendszeresen vagy alkalmanként távmunkában, otthoni munkavégzésben dolgozók aránya a korábbi 3 százalékról a 15-74 éves foglalkoztatottak körében. A vírus enyhülésével párhuzamosan, a nyár végére ismét mérséklődött a „home office"-ban, távmunkában dolgozók aránya 5 százalékra, majd ősztől, a vírus második hullámának megjelenésével ismét növekedni kezdett (KSH 2021).

Jelen írásban a biztonság három dimenziójának (egészség, munka és emberi kapcsolatok) összefüggésében a home office jelenségét állítjuk középpontba, és annak pozitív és negatív jellemzőit vizsgáljuk meg az emberi kapcsolatok szempontjából. Az otthoni munkavégzés lehetôsége egyrészt értelmezhetô a vírustól való védelem egy formájaként: azok a munkavállalók, akik otthonról végezhetik munkájukat, dönthetnek úgy, hogy nem lépnek ki egyáltalán otthonukból, és így, fizikai izoláltsággal védik magukat a vírustól. Az így kialakuló helyzet azonban a személyes kontaktusok csökkenését eredményezheti, mely negatívan hathat az egyének mentálhigiénés állapotára. Az elemzések során a távmunka és home office kifejezések alatt is az otthoni munka- végzést értjük. Azt feltételezzük, hogy a home office jobban véd a vírustól, mivel az otthonról dolgozók kevésbé vannak kitéve az olyan, a vírus szempontjából kockázatos tevékenységeknek, mint a tömegközlekedés vagy a külföldi utazás. Másrészt azt is feltételezzük, hogy a home office-ban dolgozók kevesebb személlyel találkoznak, mint a nem otthonról dolgozók és ezáltal jobban veszélyezteti őket a társas izoláció.

\section{Szakirodalmi elözmények}

Sokan (pl. Clair et al. 2021) felhívták már a figyelmet a világjárvány, illetve a megfékezésére tett intézkedések lehetséges negatív hatásaira: a gazdasági életre, a munkaerópiacra, ezáltal az anyagi helyzetre, a mindennapok szervezésére, a testi és lelki egészségre és így az emberek anyagi helyzetére, illetve a társas kapcsolatok alakulására is. A távolságtartást és ezáltal a koronavírus terjedésének csökkentését célzó lezárások, karanténidőszakok, illetve távolságtartást előíró rendelkezések a mindennapi emberi kapcsolatok szövetére is jelentős hatással voltak. Egyrészt persze megtapasztalhattuk a közeli kapcsolatainkkal, legtöbb esetben családtagjainkkal való kényszerú összezártság pozitív és negatív hatásait, illetve a társadalmi szolidaritás megnyilvánulásait is, ugyanakkor sokak esetében a járványhelyzet az elmagányosodás, kapcsolatvesztés tapasztalatát hozta. Márpedig a magány sérülékennyé teszi az embert és negatív hatással van mind a fizikai, mind a lelki egészségre (Diener 2000; KaplanCassel-Gore 1977). Az eddigi empirikus vizsgálatok szerint ez a hatás különösképp érintette a fiatal, illetve idős lakossági csoportokat (Eurofound, 2020).

A COVID-19 világjárvány első hulláma alatt gyújtött empirikus adatok számos országban jelzik a személyközi kapcsolatok beszúk ülését. Az Egyesült Királyságban a megfigyelt napi kapcsolatfelvételek száma 74 százalékkal csökkent (Jarvis et al. 2020) 2020. március végére (átlag 
10,8 fơről 2,8 fơre). Zhang et al. (2020) Wuhan és Shanghai lakosságát vizsgálta ebból a szempontból a járvány kitörése előtt és után, és 7-8-szoros csökkenést mutattak ki a lezárások hatására, mivel a legtöbb kapcsolathálózat az együtt élő háztartástagokra szúkült le. Bosetti et al. (2020) azt találta, hogy Franciaországban 70 százalékos a csökkenés, napi átlagosan 3,3 kapcsolatfelvételre szúkült, ugyanakkor jelentős különbségeket találtak életkor szerint: az idősek esetében az átlag 1,7 fó, míg a fiatalok esetében 3,6 fó volt (Bosetti et al. 2020). Luxemburgban is 80 százalékos kapcsolatszám-csökkenést mértek az első hullám során a lezárások alatt, az átlagos kapcsolatszám a fiatalok esetén 4,2, a 64 évnél idősebben körében 1,7 fő volt (Latsuzbaia et al. 2020). Egy összehasonlító európai vizsgálat ugyanakkor azt találta, hogy az 1994 és 2001 között születetteket fokozottabban érintette a járvány, mint az idősebb korosztályokat, amit a fiatal generáció eredendően fokozottabb társas, fizikai és munkaerópiaci aktivitásával magyaráztak, mivel a lezárások miatt ezekbe a tevékenységekbe történtek a legdrasztikusabb beavatkozások (Kaspersky 2020). Ezt a megállapítást más összehasonlító elemzések is megerősítették (pl. Eurofound 2020).

Nemcsak a kapcsolathálózatok mérete, hanem a kapcsolatok minősége is megváltozhatott a járvány és következményei hatására. Schmid et al. (2021) a foglalkozási státusz járványhelyzet miatti változása (home office és rövidített munkaidő) tekintetében vizsgálta az együtt élő párok kapcsolatminőségének változását: a vizsgált párok ötöde pozitív változásról számolt be, 40 százalék nem tapasztalt változást, ugyanakkor 40 százalékuk a kapcsolat negatív irányú változásáról számolt be. Összegzésként a szerzők arra jutottak, hogy a COVID-járvány miatti foglalkozási státuszban bekövetkezett változásoktól függetlenül, összességében csökkent a párkapcsolattal való elégedettség válaszadóik körében. A COVID-19 járvány kapcsolatokra, a család mentális egészségére gyakorolt negatív hatásáról más kutatások is beszámoltak (pl. Balzarini et al. 2020; Biroli et al. 2020).

Magyarországon a COVID-19 járvány kitörése után egy évvel készített felmérésben többek között kitértek a társas kapcsolatok vizsgálatára is (Bíró-Nagy-Szászi 2021). A többség $(70 \%)$ nem számolt be változásról a karantén és a társas távolságtartás időszaka alatt, 19 százalék esetében szorosabbá váltak a családi kapcsolatok, illetve a párkapcsolatuk (16\%), ugyanakkor romlásról számolt be a családi kapcsolatok tekintetében 8 , illetve a párkapcsolatok tekintetében 5 százalék. A baráti kapcsolatok elhidegüléséről 19, megerősödéséről 7 százalék számolt be. A válaszadók 11 százalékának a munkakapcsolatai, 8 százalékának a családi kapcsolatai, 5 százalékának a párkapcsolata hidegült el. A megkérdezettek 44 százaléka kapott segítséget a válság idején a családjától, ami ugyanakkor azt is jelenti, hogy a megkérdezettek több mint fele nem számíthatott ilyen segítségre, ami azért is különösen problémás, mert a túlnyomó többség saját bevallása szerint sem munkahelyétől, sem kormány- tól, sem a helyi önkormányzattól nem kapott segítséget. A vizsgálatban a válaszadók 69 százaléka mondta, hogy a járvány miatt csak a legszükségesebb okok miatt hagyják el otthonaikat. A félelem, bizonytalanságérzet az élet szinte minden vizsgált területén jelentős: az együtt élő párok tizede erősen tartott attól, hogy párja agresszívvá válik a karantén alatt, az állásukat veszítók különösképpen. 55 százalék félt attól, hogy kevesebb lesz a fizetése, 45 százalék attól, hogy elveszti az állását. Minden negyedik ember meg is tapasztalta anyagi helyzetének romlását. A KSH-nál mértnél nagyobb mértékben, a válaszadók tizede be is számolt állásvesztésről. 18 százalék dolgozott home office-ban - ez a magasabb iskolai végzettségúek körében gyakrabban fordult elő, ezért körükben a gyerekek ellátása még inkább problémát jelentett (Biró-Nagy-Szászi 2021). Az otthoni munkavégzésre vonatkozóan a KSH adataihoz inkább hasonló eredményeket közölt Sik és Zakariás (2021). 2020 júliusában egy 800 fös reprezentatív online mintán végzett kutatásuk szerint, ami a szolidaritási mező fenomenológiai mintázatait vizsgálta, az összes megkérdezett 11 százaléka otthon, 38 százaléka munkahelyén, míg 9 százaléka részben otthon, részben munkahelyén dolgozott a karantén alatt. Kényszerszabadságon volt 3 százalékuk, és 39 százalék volt azoknak az aránya, akiknek nem volt fizetett munkája (Sik-Zakariás 2021).

2020 májusában, a korlátozások alatt Fodor et al. (2020) egy országos reprezentatív survey keretein belül mérte fel a járvány okozta változásokat a munkaerópiacon. E felmérés szerint a munkavállalók negyede otthonról végezte a munkáját (home office), további negyedük kényszerszabadságon volt, a dolgozók közel fele pedig továbbra is bejárt a munkahelyére. A nők 32 , míg a férfiak 24 százaléka dolgozhatott otthonról, míg bejárni a nők 40, a férfiak 51 százalékának kellett. A home office lehetôsége iskolai végzettség szerint is különbözött: a szakmunkások 5 , a diplomások 55 százaléka folytathatta otthonról a munkavégzést. A kutatás összefüggést talált a lakóhely és a férfiak otthoni munkavégzése közt: a fóvárosi férfiak 40, a községben élők 15 százaléka dolgozott home office-ból, a Dél-Dunántúlon pedig mindöszsze a férfiak 10 százaléka. Kutatásukban a home office előnyeire és hátrányaira vonatkozó állításokból kiderült, hogy a többség átlagosan meg volt elégedve az otthoni munkavégzéssel (2,6 5-ös skálán), de a nehézségeket nagyobbnak értékelték a nók, mint a férfiak $(2,8$ és 2,4$)$, valamint a 12 éven aluli gyereket nevelők.

A jelen tanulmányban használt adatfelvétellel egy időben, az első hullám alatt 2020. április 25 . és május 4 . között készített, a magyar felnőtt lakosságot reprezentáló adatfelvétel $(\mathrm{N}=878)$ során megkérdezettek 18 százaléka számolt be jelentős jövedelemcsökkenésrőll, 7 százalékuk munkahelye elvesztéséről. Az adatfelvételt megelőző hét során csak a válaszadók 36 százaléka hagyta el napi rendszerességgel az otthonát, míg 21 százalék csak hetente egyszer, 14 százalék pedig egyáltalán nem. Ez utóbbi csoportba zömében idős emberek tartoztak. 
A bevásárlásban családtagjuktól vagy külön háztartásban élő rokonuktól, ismerősüktől vagy esetleg egy számukra korábban ismeretlen személytől a válaszadók közel fele (49\%) kapott segítséget (Tóth-Hudácskó 2020).

\section{Vizsgálati anyag és módszer}

A tanulmányban egy 2020 májusában a Szinapszis Kft. által telefonon megkeresett országos, 1001 fös reprezentatív minta segítségével készült adatbázis eredményeit használjuk fel. Az adatbázist nem és korcsoport szerint súlyoztuk. Az adatfelvétel egyrészt a vírushelyzetre vonatkozó kérdéseket tartalmazott, másrészt a válaszadóknak egy ún. kapcsolati naplót ${ }^{1}$ is ki kellett tölteniük a kérdezóbiztosok segítségével. A kapcsolati naplóban a válaszadóknak meg kellett nevezniük minden olyan személyt, akikkel a kérdezést megelőző napon ${ }^{2}$ valamilyen módon beszéltek (pl. személyesen vagy telefonon). Minden olyan beszélgetést meg kellett nevezniük, ami a köszönésen kívüli további kommunikációt foglalt magába. A naplóban továbbá meg kellett jelölniük a megnevezett személy nemét és életkorát, valamint a kérdezetthez füződő viszonyukat (pl. társ, szülő, barát stb.), azt, hogy együtt élnek-e az adott személlyel, vagy sem, a beszélgetés hosszát, az adott személlyel történő beszélgetés gyakoriságát az elmúlt félévben, valamint azt is, hogy a kérdezett mennyire kedveli a megnevezett személyt.

Mivel jelen tanulmányban az otthoni és a munkahelyen történő munkavégzésben dolgozók különbségeit kívánjuk feltárni a vírussal szembeni védelem és a személyes kapcsolathálózati struktúra különbségei szempontjából, ezért elemzésünkben a teljes minta csak azon szegmensét (továbbiakban alminta) vizsgáljuk, akik a kérdezést megelőző héten legalább egy óra jövedelmet biztosító munkát $(\mathrm{N}=410)$ végeztek.

A továbbiakban először bemutatjuk az alminta megoszlását a fóbb demográfiai jellemző́k és a munkavégzés helyszíne szerint, majd különböző indikátorok mentén megvizsgáljuk, hogy az otthoni munkavégzés valóban biztonságot nyújtott-e a vírussal szemben (vagyis: kevésbé kerültek-e olyan helyzetbe az otthonról dolgozók a nem otthonról dolgozókhoz képest, ami víruskockázatot jelent). Végül a személyes találkozások alapján a kapcsolathálózat jellegzetességeit vetjük össze a két vizsgálati csoportban.

\footnotetext{
${ }^{1}$ A kapcsolati napló módszertanáról részletesen lásd: Huszti É. (2015): Megis mer-hetem. A személyes kapcsolathálózat feltárásának új formája: kapcsolati napló. Debreceni Egyetemi Kiadó; Dávid B. et al. (2017): Kapcsolati napló pluszok és mínuszok. Új módszer az egocentrikus kapcsolathálózat kutatásában. In: Kovách I. (szerk.): Társadalmi integráció. Belvedere Meridionale Kiadó.

2 Ebben a tanulmányban csak azok szerepelnek, akik a naplót egy hétköznapra vonatkozóan töltötték ki.
}

\section{Vizsgálati eredmények}

\section{A munka biztonsága: kik dolgoznak otthonról?}

A kérdezést megelőző héten legalább egy óra jövedelmet biztosító munkát végző́k $(\mathrm{N}=410) 29,5$ százaléka teljes mértékben, 3,8 százaléka pedig részben otthonról dolgozott a kérdezés idején. További 13,2 százalékuk nem dolgozott a kérdezés napján, a kérdezettek másik fele pedig nem élhetett az otthoni munkavégzés lehetőségével (1. táblázat). Mivel tanulmányunkban azt vizsgáljuk, hogy az otthoni munkavégzés védelmet nyújt-e a vírustól, és mindeközben okoz-e társas izolációt, a további elemzésbe csak a teljesen otthonról dolgozók $(\mathrm{N}=219)$ és az egyáltalán nem otthonról dolgozók $(\mathrm{N}=121)$ csoportjait vonjuk be.

A fenti leírás szerinti alminta $(\mathrm{N}=340)$ demográfiai megoszlását nem, iskolai végzettség, régió, a lakóhely típusa és egészségi állapot alapján elemeztük (2. táblázat). A munkájukat otthonról végzők közt nem volt szignifikáns különbség nemek szerint, közel fele-fele arányban voltak az otthonról dolgozók közt nők és férfiak (47 és 53 százalék). Szignifikáns különbség volt azonban a korábbi kutatásokhoz hasonlóan a home office és az iskolai végzettség közt: a magasabb iskolai végzettséggel rendelkező́k közt magasabb volt az otthonról dolgozók aránya. Míg a home office-ban dolgozók 64 százaléka diplomás, addig a nem home office-ban dolgozók körében ez az arány mindössze 17,5 százalék.

Regionálisan és településtípus szerint is szignifikánsan különbözött, hogy milyen arányban dolgoztak a munkavállalók home office-ból. Az otthonról dolgozók fele $(50,8 \%)$ a közép-magyarországi régióban él, egyharmaduk $(32,5 \%)$ városban. Legkevesebben a Dunántúlról (Nyugat-Dunántúl 4,2\%, Dél-Dunántúl 4,2\%, KözépDunántúl 5\%), illetve megyeszékhelyekről dolgoztak otthonról (16,3\%).

Az egészségi állapot szerint is szignifikánsan különbözött az alminta: azok, akik valamilyen krónikus betegségben szenvednek, nem tudtak nagyobb arányban otthonról dolgozni, mint a krónikus betegségben nem szenvedők.

1. táblázat |Az alminta megoszlása a munkavégzés helyszíne szerint*

\begin{tabular}{lrc}
\hline $\begin{array}{l}\text { Ön tegnap otthonából végezte } \\
\text { a munkáját? }\end{array}$ & $\mathrm{N}$ & $\%$ \\
\hline Igen, teljesen & 121 & 29,5 \\
Igen, részben & 16 & 3,9 \\
Nem & 219 & 53,4 \\
Van munkája, de nem dolgozott & 54 & 13,2 \\
\hline Összesen & 410 & 100 \\
\hline
\end{tabular}

*A táblázatban súlyozott esetszámokat közlünk.

Forrás: saját szerkesztés 
2. táblázat |Az alminta megoszlása demográfiai jellemzők szerint*

\begin{tabular}{|c|c|c|c|c|c|c|}
\hline & \multicolumn{2}{|c|}{ Home office } & \multicolumn{2}{|c|}{ Nem home office } & \multicolumn{2}{|c|}{ Összesen } \\
\hline & $\mathrm{N}$ & $\%$ & $\mathrm{~N}$ & $\%$ & $\mathrm{~N}$ & $\%$ \\
\hline \multicolumn{7}{|c|}{$\operatorname{Nem}(p=0,72 ;$ Cramer's $V=0,187)$} \\
\hline Férfi & 64 & 52,9 & 132 & 60,2 & 196 & 57,6 \\
\hline Nő & 57 & 47,1 & 87 & 39,8 & 144 & 42,3 \\
\hline Összesen & 121 & 100 & 219 & 100 & 340 & 100 \\
\hline \multicolumn{7}{|c|}{ Iskolai végzettség ( $p=0,000$; Cramer's $V=0,472)$} \\
\hline Legfeljebb 8 általános & 9 & 7,2 & 32 & 14,5 & 40 & 11,9 \\
\hline Szakmunkás & 11 & 8,7 & 67 & 30,4 & 77 & 22,7 \\
\hline Érettségi & 25 & 20,5 & 82 & 37,6 & 107 & 31,6 \\
\hline Diploma & 77 & 63,6 & 38 & 17,5 & 115 & 33,8 \\
\hline Összesen & 122 & 100 & 219 & 100 & 339 & 100 \\
\hline \multicolumn{7}{|c|}{ Régió ( $p=0,000$; Cramer's $V=0,312$ ) } \\
\hline Dél-Alföld & 15 & 12,4 & 26 & 11,7 & 41 & 12,1 \\
\hline Dél-Dunántúl & 5 & 3,8 & 30 & 13,6 & 35 & 10,3 \\
\hline Észak-Alföld & 17 & 14,4 & 35 & 15,9 & 52 & 15,3 \\
\hline Észak-Magyarország & 11 & 9,2 & 26 & 11,6 & 37 & 10,9 \\
\hline Közép-Dunántúl & 6 & 5,1 & 30 & 13,8 & 36 & 10,6 \\
\hline Közép-Magyarország & 61 & 50,7 & 52 & 23,7 & 113 & 33,2 \\
\hline Nyugat-Dunántúl & 5 & 4,4 & 21 & 9,7 & 26 & 7,6 \\
\hline Összesen & 120 & 100 & 220 & 100 & 340 & 100 \\
\hline \multicolumn{7}{|c|}{ Lakóhely típusa ( $p=0,000$; Cramer's $V=0,248$ ) } \\
\hline Budapest & 38 & 31,4 & 26 & 12,0 & 64 & 18,9 \\
\hline Megyeszékhely & 20 & 16,7 & 38 & 17,2 & 58 & 17,1 \\
\hline Város & 40 & 32,6 & 91 & 41,7 & 131 & 38,3 \\
\hline Község & 23 & 19,3 & 64 & 29,1 & 87 & 25,7 \\
\hline Összesen & 121 & 100 & 219 & 100 & 340 & 100 \\
\hline \multicolumn{7}{|c|}{ Krónikus beteg? ( $p=0,023$; Cramer's $V=0,123)$} \\
\hline Igen & 18 & 14,9 & 55 & 25,4 & 73 & 21,5 \\
\hline Nem & 103 & 85,1 & 164 & 74,6 & 267 & 78,5 \\
\hline Összesen & 121 & 100 & 219 & 100 & 340 & 100 \\
\hline
\end{tabular}

*A táblázatban súlyozott esetszámokat közlünk.

Forrás: saját szerkesztés

\section{Az egészség biztonsága: az otthoni munkavégzés védelem a virustól}

Az adatokból látható, hogy az otthoni munkavégzés több indikátor szerint is védte a munkavállalókat a megfertőződés veszélyétől. Az otthonról dolgozók közel egyharmada nem hagyta el lakását a kérdezést megelőző napon, míg a nem home office-ban dolgozóknak mindösszesen l százaléka. A nem otthonról dolgozók átlagosan 599 percet, vagyis közel 10 órát töltöttek otthonukon kívül a kérdezést megelőző napon, míg a home office-ban dolgozók átlagosan 117 percet (közel 2 órát) (3. táblázat). A tömegközlekedési eszközök használatát a nem otthonról dolgozók is igyekezték elkerülni, hiszen azok közül, akik elhagyták lakásukat a kérdezést megelő- ző napon, mindösszesen 16 százalékuk vette igénybe ezt a szolgáltatást. Az otthonról dolgozók viszont ennél is alacsonyabb arányban $(4,8 \%)$ utaztak valamely tömegközlekedési eszközzel (4. táblázat). Míg a nem otthonról dolgozók 2,7 százaléka járt a kérdezést megelőző hónapban külföldön, addig a home office-ban dolgozók közül senki sem (4. táblázat). A válaszadóktól azt is megkérdeztük, hogy amennyiben a kérdezést megelőző napon kimozdultak otthonukból, akkor hány darab védőfelszerelést viseltek (kesztyú, maszk, védőruha). Eszerint is szignifikáns különbség mutatkozik a két csoport között: ebben az esetben a nem otthonról dolgozók voltak azok, akik átlagosan több felszerelést viseltek (3. táblázat). Az otthonról dolgozók eszerint nem védték jobban magukat a vírustól, amikor kimozdultak lakhelyükről, 
A saját otthonon kívül töltött percek átlagos száma (a kérdezést megelőző napon) és a kimozduláskor viselt védőfelszerelések átlagos száma a munkavégzés helye szerint*

\begin{tabular}{|c|c|c|c|c|c|}
\hline & & $\begin{array}{l}\text { Nem home office } \\
(\mathrm{N}=219)\end{array}$ & $\begin{array}{l}\text { Home office } \\
(\mathrm{N}=121)\end{array}$ & Összesen & p-érték \\
\hline \multirow[t]{2}{*}{ Otthonon kívül töltött percek száma } & Átlag & 598,58 & 116,68 & 427,46 & \multirow{2}{*}{$\mathrm{p}=0,000$} \\
\hline & Szórás & 276,13 & 189,53 & 339,29 & \\
\hline \multirow[t]{2}{*}{ Viselt védőfelszerelések száma kimozduláskor } & Átlag & 1,19 & 0,78 & 1,08 & \multirow{2}{*}{$\mathrm{p}=0,000$} \\
\hline & Szórás & 0,92 & 0,91 & 0,93 & \\
\hline
\end{tabular}

*A táblázatban súlyozott esetszámokat közlünk.

Forrás: saját szerkesztés

ugyanakkor ez az eredmény értelmezhető úgy is, hogy ők kevésbé is érezték magukat veszélyeztetve a vírus által, mivel kevésbé is voltak kitéve kockázatos tevékenységeknek (rövidebb ideig voltak távol otthonuktól, kevésbé kellett tömegközlekedéssel utazniuk, nem kellett a munkahelyükre bejárni).

\section{A személyes kapcsolatok biztonsága: társas elszigetelödés?}

Az otthonról és nem otthonról dolgozó munkavállalók kapcsolati struktúráját tekintve szignifikáns különbség mutatkozik a személyes találkozások számában. A home office-ban dolgozók a kérdezés napján átlagosan két személlyel találkoztak személyesen, míg a nem otthonról

4. táblázat A munkavégzés helye, a tömegközlekedéssel való utazás (ha kimozdult otthonról), valamint a külföldre történő utazás*

\begin{tabular}{lcccc}
\hline $\begin{array}{l}\text { Tömegközlekedéssel utazott } \\
\text { (a kérdezést megelőző napon) }\end{array}$ & & $\begin{array}{l}\text { Nem home } \\
\text { office }\end{array}$ & $\begin{array}{l}\text { Home } \\
\text { office }\end{array}$ & Összesen \\
\hline Igen & $\mathrm{N}$ & 35 & 4 & 39 \\
& $\%$ & 16,2 & 4,8 & 13,0 \\
\hline Nem & $\mathrm{N}$ & 181 & 79 & 260 \\
& $\%$ & 83,8 & 95,2 & 87,0 \\
\hline Összesen & $\mathrm{N}$ & 216 & 83 & 299 \\
& $\%$ & 100 & 100 & 100 \\
\hline
\end{tabular}

$\mathrm{p}=0,009 ;$ Cramer's $\mathrm{V}=0,151$

\begin{tabular}{lcccc}
\hline $\begin{array}{l}\text { Járt külföldön az elmúlt egy } \\
\text { hónapban }\end{array}$ & & $\begin{array}{l}\text { Nem home } \\
\text { office }\end{array}$ & $\begin{array}{l}\text { Home } \\
\text { office }\end{array}$ & Összesen \\
\hline Igen & $\mathrm{N}$ & 6 & 0 & 6 \\
& $\%$ & 2,7 & 0,0 & 1,8 \\
\hline Nem & $\mathrm{N}$ & 213 & 121 & 334 \\
& $\%$ & 97,3 & 100,0 & 98,2 \\
\hline Összesen & $\mathrm{N}$ & 219 & 121 & 340 \\
& $\%$ & 100 & 100 & 100 \\
\hline
\end{tabular}

A táblázatban súlyozott esetszámokat közlünk.

A Khí-négyzet próba feltételei nem állnak fenn.

Forrás: saját szerkesztés dolgozók átlagosan öt személlyel. A rokoni és egyéb kapcsolatokat külön vizsgálva ugyanakkor az is látható, hogy a rokonokkal történő találkozások számában nincs szignifikáns különbség, és még a kérdezettekkel nem együtt élő rokonokkal való találkozások száma sem tér el szignifikánsan a két vizsgálati csoportban. Különbség a nem családtagokkal történő találkozások számában mutatkozik: a nem home office-ban dolgozók átlagosan három olyan személlyel találkoztak, akikkel nem állnak rokoni kapcsolatban, míg az otthonról dolgozók átlagosan egy ilyen személlyel találkoztak (5. táblázat).

Az 5. táblázat adatai alapján látható, hogy a fent jelzett különbséget kifejezetten a munkatársakkal történő találkozások száma közti eltérés magyarázza. A barátokkal és a szomszédokkal való találkozási gyakoriság nem mutatott szignifikáns különbséget a két csoport között. A home office eszerint nem vezetett magasabb fokú izoláltsághoz, a családi és baráti kapcsolatok kompenzálták az otthonról dolgozókat. Az adatok ugyanakkor azt is mutatják, hogy az otthonról dolgozók ugyanannyira látogatták a velük nem együtt élö rokonaikat, és ugyananynyira találkoztak a barátaikkal is, mint a munkahelyükre bejáró dolgozók; tehát ilyen szempontból nem védték magukat jobban a vírustól.

A találkozások helyszínét vizsgálva (5. táblázat) a munkahelyi találkozásokon kívül, a két csoport között szignifikáns különbség volt a közterületen való találkozások számát tekintve is: azok, akik nem otthonról dolgoztak, értelemszerüen többször találkoztak másokkal közterületeken, mint azok, akik home office-ban voltak. A lakásban, az üzletben és egyéb helyeken történő találkozások számában nem volt jelentős különbség a két csoportban.

\section{Vizsgálati eredmények értékelése, megvitatása, összefoglalása és következtetések levonása}

Az egészség védelme a COVID-19 járvány alatt közös társadalmi érdek, amit nagyban segített az otthoni munkavégzés széles körü bevezetése. Ugyanakkor társadalmi érdek az is, hogy a post-Covid időszakban a mentális egészségünkkel törődjünk. Tanulmányunkban épp ezért azt vizsgáltuk, hogy az otthoni munkavégzésnek vajon 
5. táblázat |A személyes találkozások átlagos száma kapcsolattípusonként, a találkozás helye szerint és a munkavégzés helye szerint*

\begin{tabular}{|c|c|c|c|c|c|}
\hline & & $\begin{array}{l}\text { Nem home office } \\
(\mathrm{N}=219)\end{array}$ & $\begin{array}{l}\text { Home office } \\
(\mathrm{N}=121)\end{array}$ & Összesen & p-érték \\
\hline \multirow[t]{2}{*}{ Összes személyes találkozás száma } & Átlag & 4,55 & 2,44 & 3,80 & \multirow{2}{*}{$\mathrm{p}=0,000$} \\
\hline & Szórás & 3,70 & 2,27 & 3,42 & \\
\hline \multirow[t]{2}{*}{ Családtagokkal } & Átlag & 1,51 & 1,57 & 1,53 & \multirow{2}{*}{$\mathrm{p}=0,701$} \\
\hline & Szórás & 1,45 & 1,57 & 1,50 & \\
\hline \multirow[t]{2}{*}{ Nem családtagokkal } & Átlag & 2,73 & 0,71 & 2,01 & \multirow{2}{*}{$\mathrm{p}=0,000$} \\
\hline & Szórás & 3,06 & 1,32 & 2,75 & \\
\hline \multirow[t]{2}{*}{ Együtt élő családtagokkal } & Átlag & 1,13 & 1,33 & 1,20 & \multirow{2}{*}{$\mathrm{p}=0,183$} \\
\hline & Szórás & 1,27 & 1,38 & 1,31 & \\
\hline \multirow[t]{2}{*}{ Nem együtt élő családtagokkal } & Átlag & 0,38 & 0,25 & 0,33 & \multirow{2}{*}{$\mathrm{p}=0,114$} \\
\hline & Szórás & 0,85 & 0,67 & 0,79 & \\
\hline \multirow[t]{2}{*}{ Baráttal, barátnővel } & Átlag & 0,19 & 0,15 & 0,18 & \multirow{2}{*}{$\mathrm{p}=0,573$} \\
\hline & Szórás & 0,62 & 0,47 & 0,57 & \\
\hline \multirow[t]{2}{*}{ Jelenlegi szomszéddal } & Átlag & 0,08 & 0,14 & 0,10 & \multirow{2}{*}{$\mathrm{p}=0,309$} \\
\hline & Szórás & 0,44 & 0,66 & 0,53 & \\
\hline \multirow[t]{2}{*}{ Jelenlegi munkatárssal } & Átlag & 1,83 & 0,12 & 1,23 & \multirow{2}{*}{$\mathrm{p}=0,000$} \\
\hline & Szórás & 2,68 & 0,57 & 2,33 & \\
\hline \multirow[t]{2}{*}{ A kérdezett vagy a kapcsolati személy lakásában } & Átlag & 1,57 & 1,74 & 1,63 & \multirow{2}{*}{$\mathrm{p}=0,342$} \\
\hline & Szórás & 1,55 & 1,77 & 1,63 & \\
\hline \multirow[t]{2}{*}{ A kérdezett vagy a kapcsolati személy munkahelyén } & Átlag & 2,21 & 0,11 & 1,47 & \multirow{2}{*}{$\mathrm{p}=0,000$} \\
\hline & Szórás & 2,90 & 0,58 & 2,56 & \\
\hline \multirow[t]{2}{*}{ Közterületen } & Átlag & 0,35 & 0,14 & 0,27 & \multirow{2}{*}{$\mathrm{p}=0,020$} \\
\hline & Szórás & 1,08 & 0,53 & 0,93 & \\
\hline \multirow[t]{2}{*}{ Üzletben } & Átlag & 0,14 & 0,08 & 0,12 & \multirow{2}{*}{$\mathrm{p}=0,248$} \\
\hline & Szórás & 0,67 & 0,37 & 0,58 & \\
\hline \multirow[t]{2}{*}{ Egyéb helyen } & Átlag & 0,23 & 0,22 & 0,22 & \multirow{2}{*}{$\mathrm{p}=0,626$} \\
\hline & Szórás & 0,82 & 0,56 & 0,74 & \\
\hline
\end{tabular}

A táblázatban súlyozott esetszámokat közlünk.

Forrás: saját szerkesztés

milyen hatása volt az egyén társas kapcsolataira. Azt feltételeztük, hogy az otthoni munkavégzés, a munkatársakkal való érintkezés leredukálása, a munkába történő eljutás, munkával összefüggő külföldi utazások kiesése egyrészt csökkentik a megfertőződés veszélyét, ugyanakkor növelheti a társas izoláció esélyét is.

A teljes minta 36 százaléka dolgozott home officeban a kérdezés idején. Jellemzően azok tudtak inkább az otthoni munkavégzés lehetőségével élni, akik felsőfokú iskolai végzettséggel rendelkeztek, a közép-magyarországi régióban élnek és inkább a városiak. Az adatok alapján elmondható, hogy az otthonról dolgozók lényegesen kevesebb időt töltöttek saját otthonukon kívül, harmaduk nem is hagyta el a lakását a kérdezést megelőző napon. A tömegközlekedést is kisebb arányban használták, mint azok, akik bejártak a munkahelyükre és senki sem volt közülük külföldön. Ezek a munkavégzéshez kapcsolódó mindennapos cselekvések, azaz azok nélkülözése, hozzájárulhattak a fertőzés elkerüléséhez az ott- honról dolgozók esetében. Az érem másik oldalát vizsgálva, azt ugyanis, hogy vajon ez a magatartás nem vezetett-e az otthonról dolgozók társas izolációjának növekedéséhez, megállapítható, hogy míg a home office-ban dolgozók a kérdezés napján két személlyel találkoztak személyesen, addig a nem otthonról dolgozók öttel. Míg a rokonok számában - akár egy fedél alatt élnek a megkérdezettel, akár nem - nem találtunk szignifikáns különbséget az otthonról dolgozók és a munkába eljárók között, addig a nem rokonokkal való találkozás lényegesen magasabb a nem home office-ban dolgozók körében. A különbséget elsősorban éppen a munkahelyi kapcsolatok jelentették. Az otthonról dolgozókat a családtagokkal, barátokkal és esetenként a szomszédokkal történő találkozások védték a társas izoláció veszélyeitől. A home office-ban dolgozók tehát egyrészt kevésbé voltak kitéve a fertőzésveszélynek, másrészt emocionálisan és fizikailag közeli kapcsolataik megvédték őket a társas izoláció veszélyétől. 
A koronavírus idején a karantén bevezetése mindenekelőtt a fizikai egészség megőrzését igyekezett biztosítani össztársadalmi szinten. Ezzel együtt, mintegy a mérleg másik oldalán a mentális egészség rosszabbodása, a személyes kapcsolatok és a munkával kapcsolatos bizonytalanság állt. Eredményeink - a hivatkozott nemzetközi adatokkal bár csak részben összehasonlíthatók - mintha kisebb mértékben jeleznék a személyközi kapcsolatok beszúkülését. Ugyanakkor megerősítik, azt a megfigyelésünket, miszerint krízishelyzetben (mint amilyen a rendszerváltás ideje is volt) különösen felértékelődnek a családi és a családon kívüli szoros kapcsolatok, az ún. erős kötések. Ahhoz, hogy a jelenség mögött álló mechanizmusokat megértsük, további mélyfúrás, kutatás szükséges: vajon ilyenkor az amúgy is meglévő kapcsolatok felfedezése történik, vagy épp ellenkezőleg az addig elhanyagolt kapcsolatok mozgósítása. Mindemellett az sem véletlen, hogy a személyes kapcsolatok mellett a munkavégzés lehetősége az, ami garantálja az egyén számára a biztonságérzetet.

\section{Irodalomjegyzék}

Balzarini, R., Muise, A., Zoppolat, G., Di Bartolomeo, A., Rodrigues, D., Alonso-Ferres, M., ... Slatcher, R. (2020) Love in the Time of Covid: Perceived Partner Responsiveness Buffers People from Lower Relationship Quality Associated with Covid-Related Stressors. https://www.researchgate.net/publication/341436083. [Letöltve: 2021. 07. 20.]

Biroli, P., Bosworth, S., Della Giusta, M., Di Girolamo, A., Jaworska, S. \& Vollen, J. (2020) Family Life in Lockdown. IZA Discussion Paper Series, No. 13398. http://ftp.iza.org/dp13398.pdf [Letöltve: 2021. 07. 20.]

Bíró-Nagy, A. \& Szászi, Á. (2021) Koronavírus és válságkezelés: A magyarok tapasztalatai egy év után. Friedrich-Ebert-Stiftung and Policy Solutions. http://library.fes.de/pdf-files/bueros/budapest/17768.pdf [Letöltve: 2021. 07. 20.]

Bosetti, P., Huynh, B-T., Abdou, Y.A., Sanchez, M., Eisenhauer, C., Courtejoie, N., ... Opatowski, L. (2020) Lockdown impact on age-specific contact patterns and behaviours in France. medRxiv reprint. https://doi.org/10.1101/2020.10.07.20205104 [Letöltve: 2021. 07. 20.]

Clair, R., Gordon, M., Kroon, M. \& Reilly, C. (2021) The effects of social isolation on well-being and life satisfaction during pandemic. Humanities and Social Sciences Communications, Vol. 8. No. 28 https://doi.org/10.1057/s41599-021-00710-3 [Letöltve: 2021. 07. 20.]

Dávid B., Barna I., Bóné V., Hegedűs R. \& Izsák É. (2016) A rendszerváltás családtörténetei - Huszonöt év Budapest árnyékában. Budapest: L'Harmattan
Dávid B., Lukács Á., Huszti É. \& Barna, I. (2017) Kapcsolati napló pluszok és mínuszok. Új módszer az egocentrikus kapcsolathálózat kutatásában. In: Kovách I. (ed.): Társadalmi integráció. Belvedere Meridionale Kiadó, pp. 331-359.

Diener, E. (2000) Subjective well-being: The science of happiness and a proposal for a national index. American Psychologist, Vol. 55. No. 1. pp. 34-43. https://doi.org/10.1037/0003-066X.55.1.34 [Letöltve: 2021. 07. 20.]

Eurofound (2020) Living, working and COVID-19. COVID-19 series, Publications Office of the European Union, Luxembourg

Fodor É., Gregor A., Koltai J. \& Kováts E. (2020) Az egyenlőtlenségek alakulása a koronajárvány idején Magyarországon. FriedrichEbert-Stiftung Budapest. http://library.fes.de/pdf-files/bueros/ budapest/16606.pdf [Letöltve: 2021. 07. 20.]

Jarvis, C. I., Van Zandvoort, K., Gimma, A., Prem, K., CMMID COVID-19 working group, Klepac P. ... Edmunds, W. J. (2020) Quantifying the impact of physical distance measures on the transmission of COVID-19 in the UK. BMC Med, Vol. 18. No. 124. https://doi.org/10.1186/s12916-020-01597-8 [Letöltve: 2021. 07. 20.]

Huszti É. (2015) Megismer-hetem. A személyes kapcsolathálózat feltárásának új formája: kapcsolati napló. Debreceni Egyetemi Kiadó

Kaplan, B. H., Cassel J. C. \& Gore S. (1977) Social Support and Health. Medical Care, Vol. 15. No. 5. pp. 47-58. DOI: 10.1097/00005650-197705001-00006

Kaspersky, (2020) Find your tribe. Staying connected to combat loneliness. https://media.kasperskydaily.com/wp-content/uploads/ sites/86/2020/06/09142852/KAS0739-Kaspersky-Find-yourtribe-report-v3.pdf [Letöltve: 2021. 07. 20.]

Központi Statisztikai Hivatal (KSH) (2021) Felértékelődött a távmunka a Covid19 árnyékában. http://www.ksh.hu/docs/hun/ xftp/idoszaki/koronavirus-tavmunka/index.html [Letöltve: 2021. 07. 20.]

Latsuzbaia, A., Herold, M., Bertemes. J-P. \& Mossong, J. (2020) Evolving social contact patterns during the COVID-19 crisis in Luxembourg. PLoS ONE, Vol. 15. No. 8. e0237128. https://doi. org/10.1371/journal.pone.0237128 [Letöltve: 2021. 07. 20.]

Schmid, L., Wörn, J., Hank, K., Sawatzki, B. \& Walper, S. (2021) Changes in employment and relationship satisfaction in times of the COVID-19 pandemic: Evidence from the German family Panel. European Societies, Vol. 23. Issue supl. pp. S743-S758. DOI: 10. $1080 / 14616696.2020 .1836385$

Sik D. \& Zakariás I. (2021) A szolidaritási mező - járvány idején. Socio.hu, Vol. 11. No. 1. pp. 1-30. https://doi.org/10.18030/ socio.hu.2021.1.1 [Letöltve: 2021. 07. 20.]

Tóth, I. Gy. \& Hudácskó, Sz. (2020) A koronavírus-járvány társadalmi hatásai a közvélemény-kutatások tükrében. In: Kolosi, T., Szelényi, I., Tóth, I. Gy. (eds): Társadalmi Riport 2020. https://www.tarki. hu/sites/default/files/2020-10/553_572_Toth_Hudacsko_web. pdf [Letöltve: 2021. 07. 20.]

Zhang, J., Litvinova, M., Liang, Y., Wang, Y., Wang, W., Zhao, S., ... $\mathrm{Yu}, \mathrm{H}$. (2020) Changes in contact patterns shape the dynamics of the COVID-19 outbreak in China. Science. Jun 26; Vol. 368. No. 6498. pp. 1481-1486. DOI: 10.1126/science.abb8001. Epub 2020 Apr 29. PMID: 32350060; PMCID: PMC7199529.

A cikk a Creative Commons Attribution 4.0 International License (https://creativecommons.org/licenses/by/4.0/) feltételei szerint publikált Open Access közlemény, melynek szellemében a cikk bármilyen médiumban szabadon felhasználható, megosztható és újraközölhető, feltéve, hogy az eredeti szerző és a közlés helye, illetve a CC License linkje és az esetlegesen végrehajtott módositások feltüntetésre kerülnek. (SID_1) 